\title{
Markers of Subclinical Cardiovascular Disease in Patients with Adrenal Incidentaloma
}

\author{
Magdalena Szychlińska *, Angelika Baranowska-Jurkun, Wojciech Matuszewski, \\ Katarzyna Wołos-Kłosowicz and Elżbieta Bandurska-Stankiewicz
}

Clinic of Endocrinology, Diabetology and Internal Medicine, School of Medicine, Collegium Medicum, University of Warmia and Mazury in Olsztyn, 10-900 Olsztyn, Poland; angelika_b1990@o2.pl (A.B.-J.); wmatuszewski82@wp.pl (W.M.); kat.wolos@gmail.com (K.W.-K.); bandurska.endo@gmail.com (E.B.-S.)

* Correspondence: szychlinskam@gmail.com

Received: 26 December 2019; Accepted: 5 February 2020; Published: 10 February 2020

\begin{abstract}
Due to the growing availability of imaging examinations the percentage of patients with incidentally diagnosed adrenal tumors has increased. The vast majority of these lesions are benign, non-functioning adenomas, although according to various estimates even up to $30 \%-50 \%$ of patients with adrenal incidentaloma may present biochemical hypercortisolemia, without typical clinical features of Cushing's syndrome. Adrenal adenomas secreting small amounts of glucocorticoids may cause morphological and functional changes in the myocardium and blood vessels. Early stages of cardiovascular remodeling may be observed among asymptomatic patients with adrenal adenoma. Vascular changes precede the development of cardiovascular diseases and can increase morbidity and mortality in patients with adrenal incidentaloma. This risk may result not only from the traditional risk factors. Seemingly hormonally inactive adrenal tumors can indeed produce small amounts of glucocorticoids that have metabolic implications. Therefore, evaluation of patients with incidental adrenal findings presenting with subclinical cardiovascular disease seems of particular importance.
\end{abstract}

Keywords: adrenal incidentalomas; hypercortisolism; cardiovascular risk markers

\section{Introduction}

Adrenal incidentaloma (AI) is an abnormal tissue mass in the adrenal gland with diameter $\geq 1 \mathrm{~cm}$, found during imaging examinations performed for non-endocrine reasons. AI is a significant problem in everyday clinical practice. According to various estimates its incidence ranges from $3 \%$ to $10 \%$ and increases with age. In AI patients 50\%-60\% adenomas are right, $30 \%-40 \%$ left, and $10 \%-15 \%$ are bilaterally localized [1-4].

The vast majority of these lesions are benign, hormonally inactive adenomas. Nevertheless, pheochromocytoma, aldosteronism, or overt cortisol excess due to hyperfunction may be observed in patients with AI. Cortisol excess is the most frequent endocrine dysfunction among patients with AI with a prevalence ranging from $5 \%$ to $30 \%$, primary aldosteronism has a median prevalence of $2 \%$ (range $1.1 \%-10 \%$ ) [3-8]. Pheochromocytoma is discovered in approximately $5 \%$ of patients with AI [9]. Mansmann et al. found $41 \%$ of AI to be adenomas, $19 \%$ metastases, $10 \%$ adrenal cortical carcinoma (ACC), 9\% myelolipomas, and $8 \%$ pheochromocytomas, with other benign lesions, such as adrenal cysts, ganglioneuromas, hematomas, and infectious or infiltrative lesions representing rare pathologies [10]. ACC is rare finding and can be functional or nonfunctional with regard to hormone synthesis and clinical features. Risk of ACC increases with the diameter of a tumor. ACC represent $2 \%$ of all tumors $\leq 4 \mathrm{~cm}$ in diameter and $25 \%$ of the tumors $>6 \mathrm{~cm}[11,12]$.

The pathogenesis of AI is still unknown. Some observations showed that $\mathrm{AI}$ is more frequent in older patients. That led to the notion that these tumors may be a manifestation of the ageing 
adrenal and could represent focal hyperplasia in response to ischemic injury [13]. There are hypotheses that insulin through the mitogenic action on adrenal cortex could contribute to the development of these tumors [14,15]. Additionally, alterations in the glucocorticoid feedback sensitivity of the hypothalamic-pituitary-adrenal axis may lead to subtle but chronic trophic stimulation of the adrenals by repeatedly inappropriately higher adrenocorticotropic hormone (ACTH) levels, particularly in response to stress, favoring nodular adrenal hyperplasia [16]. Germline or somatic genetic alterations are identified only in subgroups of sporadic tumors that are mainly functioning [17-19].

The presence of an AI has been associated with an increased incidence of several cardiovascular factors. Patients with AI can show a high prevalence of obesity, hypertension, diabetes mellitus, glucose intolerance, and dyslipidemia [2,20]. Cortisol potentiates cardiac angiotensin II and noradrenaline responsiveness and also stimulates the local renin-angiotensin system. High cortisol levels lead to endothelial damage, activation of inflammation, increased oxidative stress, and fibroproliferation, leading to functional and structural change in the heart and blood vessels [21,22].

\section{Objective}

The aim of the study is to discuss the selected cardiovascular risk (CVR) indicators in patients with AI.

\section{Hormonal Evaluation}

Current classification of AI based on cortisol secretion includes Cushing's syndrome (CS), autonomous cortisol secretion (ACS), possible autonomous cortisol secretion (pACS), and non-functional adrenal incidentaloma (NFAI) [6,7]. ACS, previously known as subclinical Cushing's syndrome (SCS) or subclinical hypercortisolism (SH), is a condition of biochemical hypercortisolism in the absence of clinical symptoms of CS (Table 1) [23,24]. This definition was modified in 2016 by European Society of Endocrinology in order to distinguish CS and ACS as distinct conditions that significantly differ in morbidity and mortality rates. The risk of progression of ACS to overt CS is very low [11,25-28].

Table 1. Clinical presentations of Cushing's syndrome.

\begin{tabular}{cl}
\hline 1. & Low effort tolerance, weakness. \\
\hline 2. & $\begin{array}{l}\text { Abdominal obesity with fat deposits around the face (rounded face, "moon-shaped face"), in the } \\
\text { midsection-especially on the back of the neck ("buffalo hump") and abdomen, supraclavicular fat } \\
\text { pads. }\end{array}$ \\
\hline 3. & $\begin{array}{l}\text { Skin thinning, dilatation of blood vessels on the face, plethora, wide, purple stretch marks on the } \\
\text { abdomen, thighs, hips, breasts, armpits and elbow pits, acne, hirsutism, oily skin, easy bruising, } \\
\text { petechiae, edema. }\end{array}$ \\
\hline 4. & Proximal muscle weakness. \\
\hline 5. & $\begin{array}{l}\text { Metabolic disorders: osteoporosis, pathological fractures, glucose and lipid alterations, } \\
\text { nephrolithiasis, fatty liver disease. }\end{array}$ \\
\hline 6. & Electrolyte disorders: hypokalemia, hypophosphatemia. \\
\hline 8. & Gypertension, heart failure, venous thrombosis. \\
\hline 9. & Menstrual disorders, decreased libido, impotence. \\
\hline 10. & Immunodeficiency: opportunistic infections, mycoses, severe infections. \\
\hline 11. & Psychiatric disorders: depression, euphoria, sleep disturbances, emotional lability, psychosis. \\
\hline
\end{tabular}

The recommended diagnostic test for hypercortisolism is $1 \mathrm{mg}$ overnight dexamethasone suppression test: serum cortisol $<1.8 \mu \mathrm{g} / \mathrm{dL}(50 \mathrm{nmol} / \mathrm{L})$ excludes hypercortisolism, $1.9-5 \mu \mathrm{g} / \mathrm{dL}$ (51-138 nmol/L) suggests pACS, and $>5 \mu \mathrm{g} / \mathrm{dL}(138 \mathrm{nmol} / \mathrm{L})$ with the absence of CS symptoms suggests 
ACS [6,7]. Diagnosis of ACS is highly challenging in view of the ambiguous diagnostic criteria and the accompanying metabolic disorders that are difficult to detect. The criterion of the absence of symptoms and signs is highly controversial because it relies entirely on the clinical evaluation and personal experience of single physicians.

It is suggested that cortisol secretion is a continuum between normal serum cortisol concentration and overt hypercortisolism and shows significant variability in one patient [11,29]. Thus, the use of stiff criteria causes unavoidable diagnostic errors. In addition, the reliability of other markers used in the diagnosis of ACS, such as morning ACTH levels or 24-h urinary free cortisol is low [11,30-32]. Certain diseases or medications can affect the results of dexamethasone suppression tests and may hinder diagnosis of hypercortisolism [33,34].

In $1 \%-29 \%$ of AI patients ACS can be observed, which probably correlates with increased risk of metabolic disorders and cardiovascular disease (CVD) in this group of patients [6,7,35]. Some studies indicate that even $30 \%-50 \%$ of patients with AI may present with biochemical hypercortisolism with no typical clinical features of CS [36].

ACS is associated with increased CVR and several metabolic disorders and may cause structural and functional abnormalities in myocardium and arterial wall architecture [37-45]. These patients have higher incidence of arterial hypertension, glucose metabolism impairment ranging from insulin resistance to diabetes mellitus, lipid metabolism alterations, hyperuricemia, overweight, and obesity [23,46,47]. Latest publications demonstrate higher CVR also in patients with NFAI $[48,49]$. It suggests that NFAI may secrete small amounts of glucocorticosteroids, which has metabolic consequences.

\section{Intima-Media Thickness of the Carotid Artery}

Carotid intima-media thickness (CIMT) measured with ultrasonography is a marker of the advancement of generalized atherosclerosis, including coronary artery disease [50]. CIMT is a valuable indicator of a cardiovascular event risk. CIMT progression of $0.1 \mathrm{~mm}$ correlates with $10 \%-15 \%$ increase of myocardial infarction risk and 13\%-18\% increase of stroke risk [51,52] and is directly associated with increased arterial stiffness [53].

In 2002 the study of Taumanova L. et al. that included 28 patients with SCS showed increased CIMT value compared to the control group. In 11 (39.3\%) patients with no clinical symptoms of CVD, atherosclerosis in various stages was found. Up to $87.5 \%$ of patients with SCS had multiple CVR factors, and 64\% had cardiovascular impairment [54].

Recent works have again tried to determine CVR in AI patients by assessing morphological and mechanical function of endothelium.

Androulakis I. et al. examining 60 normotensive euglycemic AI patients, have demonstrated significantly higher CIMT values in cortisol secreting AI compared to NFAI and controls. NFAI patients had higher CIMT values compared to the control group. Positive predictive value of $1 \mathrm{mg}$ overnight dexamethasone suppression test was demonstrated in CVR estimating (sensitivity was 79.2\%, specificity was $88 \%$ ) [55]. Tuna M. et al. in a group of 28 patients with NFAI and Imga et al. among 51 patients with NFAI confirmed higher IMT values compared to the control group [56,57]. Evran M. et al. have also observed higher CIMT value in 81 patients with AI compared to the control [58]. A similar conclusion was formed by Cansu G.B. et al. based on the studies conducted in 35 NFAI patients with no traditional CVD risk factors. Higher CIMT values were also showed in comparison to the control group [59]. Emral R. et al. who examined 83 patients with AI have confirmed increased CIMT in patients with NFAI. CIMT showed a positive correlation with age, homeostatic model assessment of insulin resistance (HOMA), fasting glucose, fasting insulin, total cholesterol, and fibrinogen. Fasting glucose and insulin and HOMA were significantly higher in NFAI patients than in the control group. The incidence of metabolic syndrome in the NFAI group was higher than in controls [60]. 


\section{Arterial Stiffness Index}

Stiffness, elasticity, and distensibility of large and medium arteries are major parameters used to assess arteries condition. Increased arterial stiffness is associated with increased cardiovascular morbidity and mortality and is an independent early risk factor for coronary artery disease and stroke in the general population [61]. Pulse wave analysis allows recording of arterial elasticity by measuring pulse wave velocity (PWV) or augmentation index (AIx) of peripheral or central arteries [62].

Cansu GB. et al. demonstrated higher PWV and peripheral and central AIx in patients with NFAI compared to the control group. PWV showed a positive correlation with total cholesterol, triglyceride, and insulin levels [59]. Similar conclusions were drawn by Akkan T. et al. who observed higher PWV and AIx adjusted for heart rate in NFAI patients. Authors have observed a negative correlation between PWV and 24-h urinary free cortisol levels [63]. In the study of Sbardella E. et al. significantly higher PWV in pACS patients was confirmed [64].

\section{Assessment of Endothelial Function}

An established method for assessing endothelial function is flow-mediated vasodilation (FMD) that measures arterial dilation in response to a transient period of ischemia. The decrease in FMD correlates with endothelial dysfunction and is associated with adverse future cardiovascular events $[65,66]$.

In the previously mentioned study conducted by Androulakis I. et al. in 2014, lower FMD in cortisol-producing AI as compared to NFAI and controls was demonstrated. NFAI patients had lower FMD compared to the control group [55].

\section{Echocardiography}

Left ventricular hypertrophy (LVH) is an altered proportion of myocardial fibers, vessels, and intercellular substance. In addition to cardiac muscle hypertrophy, collagen type I fibers accumulation within myocardium increases muscle stiffness [67]. Left ventricular diastolic dysfunction usually precedes myocardial hypertrophy, thus being an early indicator of micro- and macrocirculatory disorders. Coronary artery disease may also play a role in the pathogenesis of LVH. Normal muscle tissue compensates for the ischemic tissue work [68]. The presence of LVH is associated with 2- to 3-fold increase of stroke, 2- to 3-fold increase of coronary heart disease, and 3-fold increase of peripheral artery disease [69]. It was demonstrated in numerous epidemiological studies that LVH is an independent risk factor for CVD morbidity and mortality [70,71].

Multiple publications assessing the amount and distribution of epicardial fat thickness (EFT) suggest its possible use as a CVD risk marker. EFT is being considered as the new risk factor for metabolic syndrome and CVD [72]. EFT positively correlates with components of metabolic syndrome and is increased in obesity, type 2 diabetes, or polycystic ovary syndrome [73]. It seems that EFT does not only reflect other risk factors, but through secretion of proinflammatory cytokines, vasoactive substances, adipokines, and growth factors may have an independent effect on cardiac muscle, coronary arteries, and formation of atherosclerotic plaque [74]. In addition, the higher the EFT volume, the smaller the coronary artery diameter and atherosclerotic plaque becomes less calcified and more unstable. This directly increases the risk of acute coronary syndrome [75,76]. A 1-SD increment in EFT is associated with a 33\% greater risk of developing incident coronary heart disease [77]. Furthermore, correlation between EFT and increased left ventricular mass was established [56,78].

Echocardiography is the most important non-invasive method used for assessing cardiac morphology. Due to the presence of early morphological and functional changes in the myocardium in AI patients, it seems reasonable to perform this examination in this group.

Ermetici F. et al. in a group of 21 NFAI patients observed higher end-diastolic diameter (EDD), diastolic interventricular septum thickness IVSd, left ventricular mass index (LVMI), and lower mitral peak flow velocity in early diastole to peak flow velocity in late diastole ratio (E/A ratio) compared to the control group. Changes in echocardiography were greater in hypertensive AI patients than in the normotensive AI group. 
The study did not reveal a correlation between echocardiographic parameters and hormonal activity of tumors [79]. In the study of Iacobellis G. et al. in a group of 46 AI patients, greater left ventricular mass (LVM) compared to controls was observed. LVM was higher in SH than in the NFAI group. No correlation between cortisol levels and LVM was found. Among NFAI and SH patients higher EFT was observed compared to the control group [80]. In the aforementioned study of Evran M. et al. in a group of 81 subjects with $\mathrm{AI}$, higher heart rate, EDD, and end-systolic diameter (ESD) were observed in patients with NFAI and SCS as compared to controls. IVSd and posterior wall thickness at diastole (PWd) in NFAI and SCS patients were increased, and isovolumetric relaxation time (IVRT) was prolonged compared to the control group. Additionally, E/A ratio was $<1$ in up to $79 \%$ of NFAI patients, while in the control group it was only $36 \%$ of patients. No differences in the abovementioned parameters were observed between NFAI and SCS groups [58]. In the previously mentioned study conducted by Imga N.N. et al., higher values of LVM, IVSd, Pwd, IVRT, and EFT were demonstrated in comparison with the control group. In NFAI patients with no CVD left and right ventricular diastolic dysfunction and LVH were found. Importantly, this study showed a positive correlation between EFT and LVM, as well as between EFT and CIMT [55,81].

Sbardella E. et al. performed measurements of LVMI normalized to age and body surface area (LVMI/BSA) and to age, body surface area (BSA), glycated haemoglobin (HbA1c), LDL-cholesterol, and systolic blood pressure (LVMI/b2.7) in a group of 71 patients with AI. Morphological measurements showed significantly higher LVMI/BSA and LVMI/b2.7 in pACS than in the NFA group. Incidence of LVH was also higher in pACS than in the NFA group and it included both concentric and eccentric LVH. IVSd was higher in pACS than in the NFAI group. Left ventricular diastolic dysfunction estimated with the E/A ratio, was more common in patients with pACS. Decreased E/A ratio was found in NFAI patients, but it did not reach statistical significance $(p=0.07)$. In AI patients, both mean LVMI and incidence of LVH was higher in pACS than in the NFAI group [64]. Sokmen G. et al. in a group of 30 patients with NFAI also found significantly higher LVMI, IVSd, and Pwd, as compared to the control group [82].

\section{Final Assessment of the Available CVD Markers in Patients with AI}

Due to the widespread use of imaging examinations the proportion of patients with incidentally diagnosed adrenal tumors increases. That implies the need to establish a new diagnostic and therapeutic approach in this group. By definition, non-functional adrenal adenomas that produce small amounts of glucocorticoids may have metabolic consequences and play a role in the development of morphological and functional changes in the myocardium and blood vessels. Among asymptomatic NFAI patients, early stages of cardiovascular remodeling can be observed. Complex mechanisms of epithelial damage, inflammation, oxidative stress, and fibroproliferation lead to functional and structural changes in myocardium and blood vessels. It may increase CVR and mortality in AI patients [83]. Hormonal diagnostics of hypercortisolism, in particular ACS, is difficult, thus determining CVR in AI patients and incidence of subclinical CVD seems especially important. This may help to determine further therapeutic approaches.

In Table 2 we summarize all publications included in our review. In the investigated groups of AI patients an increased CIMT was observed, illustrating morphological changes in carotid arteries expressed by intimal hyperplasia and endothelial atherosclerosis, as well as increased PWV or AIx that are the indicators of arterial stiffness [54,55,58-60,63,64]. Endothelial dysfunction in the form of FMD was also observed [55]. The number of publications on echocardiographic measurements among AI patients is limited. The few available studies confirmed the presence of left ventricular hypertrophy features in this subject group: increased left ventricular EDD and ESD, IVSd, PWd, or LVMI [55,58,64,79-82]. Left ventricular diastolic dysfunction usually precedes myocardial hypertrophy, thus being an early indicator of micro- and macrocirculatory disorders. AI patients had impaired left ventricular relaxation demonstrated by decreased E/A ratio and prolonged IVRT [58]. One of the studies also demonstrated decreased E/A ratio in NFAI patients, but the level of statistical significance was not reached ( $p=0.07)$ [82]. Additionally, among AI patients, higher EFT volume was shown, probably being a new risk factor for metabolic syndrome and cardiovascular disease $[56,80,81]$. 
Table 2. Characteristic of included studies.

\begin{tabular}{|c|c|c|c|c|c|c|c|c|c|c|c|c|}
\hline \multirow{2}{*}{ Author } & \multirow{2}{*}{$\begin{array}{l}\text { Study } \\
\text { Design }\end{array}$} & \multirow{2}{*}{ Year } & \multirow{2}{*}{ Country } & \multirow{2}{*}{ Study Group } & \multirow{2}{*}{$\begin{array}{c}\text { Number of } \\
\text { Patients (M/F) }\end{array}$} & \multirow{2}{*}{ Inclusion Criteria } & \multirow{2}{*}{ Control Group } & \multirow{2}{*}{$\begin{array}{l}\text { Age } \\
\text { (Years) }\end{array}$} & \multirow{2}{*}{ BMI(kg/m2) } & \multicolumn{2}{|c|}{ Other Comorbidities } & \multirow{2}{*}{$\begin{array}{c}\text { Clinical } \\
\text { End-Points } \\
\end{array}$} \\
\hline & & & & & & & & & & DM2 (\%) & Hypertension (\%) & \\
\hline $\begin{array}{l}\text { Tauchmanova } \\
\text { et al. [23] }\end{array}$ & $\begin{array}{c}\text { Cross- } \\
\text { Sectional }\end{array}$ & 2000 & Italy & SCS & $28(9 / 19)$ & $\begin{array}{l}\text { Serum cortisol levels }>3 \\
\mu \mathrm{g} / \mathrm{dL} \text { after } 2 \mathrm{mg} \text {-DST }\end{array}$ & $\begin{array}{l}100 \text { healthy controls } \\
\text { matched for age, gender, } \\
\text { and BMI }\end{array}$ & 56 & 27 & 35.7 & 60.7 & CIMT \\
\hline $\begin{array}{l}\text { Androulakis } \\
\text { et al. [55] }\end{array}$ & $\begin{array}{c}\text { Case-control } \\
\mathrm{b}\end{array}$ & 2014 & Greece & $\begin{array}{c}\text { Normotensive, } \\
\text { euglycemic AI } \\
\text { (subgroups: CSAI, } \\
\text { NFAI) }\end{array}$ & $60(21 / 39)$ & $\begin{array}{l}\text { NFAI: serum cortisol level } \\
\leq 1.09 \mu g / d \mathrm{~d} \text { after a LDST; } \\
\text { CSAI: serum cortisol levels } \\
>1.09 \mu \mathrm{g} / \mathrm{dL} \text { after a LDDST }\end{array}$ & 32 healthy controls & $\begin{array}{l}55.6 \\
\text { (CSAI) } \\
54.6 \\
\text { (NFAI) }\end{array}$ & $\begin{array}{l}27.4 \text { (CSAI) } \\
26.6 \text { (NFAI) }\end{array}$ & 0 & 0 & CIMT, FMD \\
\hline Tuna et al. [57] & $\begin{array}{c}\text { Cross- } \\
\text { sectional }\end{array}$ & 2014 & Turkey & NFAI & 28 & $\begin{array}{l}\text { Serum cortisol levels } \leq 1.8 \\
\mu \mathrm{g} / \mathrm{dL} \text { after a } 1 \mathrm{mg} \text {-DST; if } \\
\text { plasma cortisol suppression } \\
\text { was inadequate, LDST was } \\
\text { performed. }\end{array}$ & 41 healthy controls & 46.7 & 30 & - & 39.3 & CIMT \\
\hline Imga et al. [56] & $\begin{array}{c}\text { Cross- } \\
\text { sectional }\end{array}$ & 2016 & Turkey & NFAI & $51(15 / 36)$ & $\begin{array}{c}\text { Serum cortisol levels } \leq 1.8 \\
\mu \mathrm{g} / \mathrm{dL} \text { after a } 1 \mathrm{mg} \text {-DST; if } \\
\text { plasma cortisol suppression } \\
\text { was inadequate, LDST was } \\
\text { performed. } \\
\end{array}$ & $\begin{array}{l}35 \text { healthy controls } \\
\text { matched for age, gender, } \\
\text { and BMI }\end{array}$ & 52 & 30.32 & 5 & & $\begin{array}{c}\text { CIMT, } \\
\text { echocardiogr-aphy }\end{array}$ \\
\hline Evran et al. [58] & $\begin{array}{c}\text { Cross- } \\
\text { sectional }\end{array}$ & 2016 & Turkey & $\begin{array}{l}\text { AI-subgroups } \\
\text { pACS, NFAI; } \\
\text { patients without } \\
\text { DM2, HT, coronary } \\
\text { artery disease and } \\
\text { dyslipidemia, }\end{array}$ & 81 & $\begin{array}{c}\text { NFAI: serum cortisol levels } \\
\leq 1.8 \mathrm{gg} / \mathrm{dL} \text { after } 1 \mathrm{mg} \text { DST. } \\
\text { SCS: serum cortisol levels } \\
>1.8 \text { ug/dL and ACTH } \leq 10 \\
\text { ug/dL after LDST }\end{array}$ & $\begin{array}{l}33 \text { healthy controls } \\
\text { matched for age, gender, } \\
\text { body mass index }\end{array}$ & $\begin{array}{r}49 \text { (SCS) } \\
52 \text { (NFAI) }\end{array}$ & $\begin{array}{l}31.8 \text { (SCS) } \\
28.7 \text { (NFAI) }\end{array}$ & 0 & 0 & $\begin{array}{c}\text { CIMT, } \\
\text { echocardiogr-aphy }\end{array}$ \\
\hline Cansu et al. [59] & Case-control & 2017 & Turkey & $\begin{array}{l}\text { NFAI without } \\
\text { traditional CVD } \\
\text { risk factors }\end{array}$ & $35(24 / 11)$ & $\begin{array}{c}\text { Serum cortisol levels } \\
\leq 1.8 \mu \mathrm{g} / \mathrm{dL} \text { after } 1 \mathrm{mg} \text {-DST }\end{array}$ & 35 healthy controls & 52 & - & - & - & CIMT, PWV, AIx \\
\hline Akkan et al. [63] & $\begin{array}{c}\text { Cross- } \\
\text { sectional }\end{array}$ & 2017 & Turkey & $\begin{array}{c}\text { NFAI without } \\
\text { traditional } \\
\text { cardiovascular risk } \\
\text { factors }\end{array}$ & $35(15 / 20)$ & $\begin{array}{c}\text { Serum cortisol levels } \\
\leq 1.8 \mu \mathrm{g} / \mathrm{dL} \text { after } 1 \mathrm{mg} \text {-DST }\end{array}$ & 35 healthy controls & 51 & 29.3 & - & - & AIx, PWV \\
\hline Emral et al. [60] & Case-control & 2019 & Turkey & AI & 83 & - & $\begin{array}{l}56 \text { controls, matched for } \\
\text { age, gender, BMI, waist } \\
\text { circumference, systolic } \\
\text { and diastolic BP, } \\
\text { smoking, concomitant } \\
\text { disease, and medications }\end{array}$ & - & - & - & - & CIMT \\
\hline Sbardella et al. [64] & Cross-sectional & 2018 & Italy & pACS & $71(47 / 24)$ & $\begin{array}{l}\text { pACS: cortisol levels } 1.9-5 \\
\mu \mathrm{g} / \mathrm{dL} \text { after } 1 \mathrm{mg} \text {-DST; } \\
\text { confirmed with } 2 \mathrm{mg} \text {-DST; } \\
\text { NFAI: cortisol levels } \leq 1.8 \\
\mu \mathrm{g} / \mathrm{dL} \text { after } 1 \mathrm{mg} \text {-DST }\end{array}$ & NFAI & 67 & 26.3 & 12.7 & 63.4 & $\begin{array}{c}\text { PWV, } \\
\text { echocardiogr-aphy }\end{array}$ \\
\hline
\end{tabular}


Table 2. Cont

\begin{tabular}{|c|c|c|c|c|c|c|c|c|c|c|c|c|}
\hline \multirow{2}{*}{ Author } & \multirow{2}{*}{$\begin{array}{c}\text { Study } \\
\text { Design }\end{array}$} & \multirow{2}{*}{ Year } & \multirow{2}{*}{ Country } & \multirow{2}{*}{ Study Group } & \multirow{2}{*}{$\begin{array}{c}\text { Number of } \\
\text { Patients (M/F) }\end{array}$} & \multirow{2}{*}{ Inclusion Criteria } & \multirow{2}{*}{ Control Group } & \multirow{2}{*}{$\begin{array}{c}\text { Age } \\
\text { (Years) }\end{array}$} & \multirow{2}{*}{ BMI $(\mathrm{kg} / \mathrm{m} 2)$} & \multicolumn{2}{|c|}{ Other Comorbidities } & \multirow{2}{*}{$\begin{array}{c}\text { Clinical } \\
\text { End-Points }\end{array}$} \\
\hline & & & & & & & & & & DM2 (\%) & Hypertension (\%) & \\
\hline Ermetici et al. [79] & Case-control & 2008 & Italy & $\begin{array}{c}\text { NFAI } \\
\text { without clinical or } \\
\text { subclinical } \\
\text { hypercortisolism }\end{array}$ & 21 & $\begin{array}{c}\text { Cortisol levels } \leq 1.8 \mu \mathrm{\mu g} / \mathrm{dL} \\
\text { after 1mg-DST }\end{array}$ & $\begin{array}{c}\text { Controls } \\
18 \text { normotensive obese } \\
\text { subjects matched for } \\
\text { gender and body mass } \\
\text { index (BMI) and } 20 \\
\text { normotensive lean } \\
\text { subjects }\end{array}$ & - & - & - & - & Echocardiogr-aphy \\
\hline Iacobellis et al. [80] & Cross-sectional & 2013 & Italy & $\begin{array}{l}\text { AI (subgroups: } \\
\text { NFAI, ACS) }\end{array}$ & 46 & $\begin{array}{l}\text { SCS: UFC level }>70 \text { ug } / 24 \mathrm{~h} \text {; } \\
\text { serum cortisol levels after } 1 \\
\text { mg-DST }>5 \mu \mathrm{\mu g} / \mathrm{dL} ; \text { morning } \\
\text { ACTH levels }<10 \mathrm{pg} / \mathrm{ml}\end{array}$ & 30 healthy controls & 62.6 & 28.8 & - & - & Echocardiogr-aphy \\
\hline Imga et al. [81] & Case-control & 2017 & Turkey & NFAI & $70(21 / 49)$ & $\begin{array}{c}\text { Serum cortisol levels } \\
\leq 1.8 \mu \mathrm{g} / \mathrm{dL} \text { after } 1 \mathrm{mg} \text {-DST }\end{array}$ & $\begin{array}{c}51 \text { healthy controls } \\
\text { matched for age, gender, } \\
\text { BMI }\end{array}$ & 52.4 & 30.1 & 0 & - & Echocardiogr-aphy \\
\hline Sokmen et al. [82] & Cross-sectional & 2018 & Turkey & NFAI & 30 & $\begin{array}{c}\text { Serum cortisol level } \leq 1.8 \\
\mu \mathrm{g} / \mathrm{dL} \text { after } 1 \mathrm{mg} \text {-DST }\end{array}$ & $\begin{array}{l}46 \text { properly matched } \\
\text { control subjects }\end{array}$ & 51.8 & 34.3 & 3 & 5 & Echocardiogr-aphy \\
\hline
\end{tabular}

ACTH—adrenocorticotropic hormone; ACS—autonomous cortisol secretion; AI—adrenal incidentaloma; AIx—augmentation index; BMI—body mass index; BP—blood pressure;

CIMT—carotid intima-media thickness; CSAI—cortisol secreting adrenal incidentaloma; DM2—diabetes mellitus type 2; DST—dexamethason suppression test; FMD—flow-mediated

vasodilation; HT—hypertension; LDST—-long dexamethason suppression test ( $0.5 \mathrm{mg}$ every $6 \mathrm{~h}$ for 2 days); NFAI—non-functional adrenal incidentaloma; pACS-possible autonomous

cortisol secretion; PWV—-pulse wave velocity; SCS—-subclinical Cushing's syndrome; UFC—-urinary free cortisol. ${ }^{\text {a }}$ cross-sectional study-a type of observational study design. The investigator measures the outcome and the exposures in the study participants at a specific point in time. ${ }^{b}$ case control study—a type of observational study design that looks back retrospectively to find the relative risk between a risk factor and an outcome. 
It must be highlighted that our review has a few limitations. First, summarized studies were conducted in small groups, without randomization, many without properly matched controls. Second, groups with heterogeneous inclusion criteria were compared. The vast majority of publications referred to patients with metabolic syndrome components: insulin resistance, glucose or lipid metabolism impairment, hypertension, abdominal obesity. Recent studies have also included NFAI patients without traditional CVD risk factors.

It was suggested that increased CVR in AI patients may not only result from traditional risk factors. Some studies propose that abnormal dexamethasone suppression test may be an independent CVR factor $[40,42,64]$. Studies conducted so far indicate that both ACS and NFAI patients have an increased cardiovascular risk [39-45]. This conclusion should imply an adequate therapeutic approach. There is no conclusive data on the superiority of adrenalectomy over a non-operative approach. Surgical treatment is limited to adrenal tumors with clinically significant hormone excess, and lesions suspicious of malignancy [5-7]. There are, however, few reports on the possible improvement of classic CVR factors after adrenalectomy in NFAI patients. In this group after surgery weight loss, reduction of blood pressure, lipid and fasting glucose levels were observed [84-88]. Certainly, further research is needed to verify the effect of adrenalectomy on improving CVR factors in AI.

\section{Conclusions}

1. Due to the widespread use of imaging examinations the proportion of patients with incidentally diagnosed adrenal tumors increases. It implies the need to establish a new diagnostic and therapeutic approach in this group.

2. Recent studies show that AI that produce small amounts of glucocorticoids may have metabolic consequences and play a role in the development of morphological and functional changes in the myocardium and blood vessels.

3. Functional and structural changes of cardiac muscle tissue and blood vessels may increase CVR and mortality in patients with AI.

4. Diagnosis of AI should not only include hormonal activity but also the assessment of cardiovascular complications risk with the use of available markers.

5. Further research is warranted to uncover benefits and drawbacks of adrenalectomy and its effect on CVR reduction in patients with AI.

Author Contributions: Conceptualization, M.S. and E.B.-S.; Methodology, E.B.-S.; Formal analysis, W.M. and E.B.-S.; Investigation, M.S., K.W.-K.; Resources, M.S., A.B.-J.; Data curation, M.S.; Writing-original draft preparation, M.S.; Writing—review and editing, M.S.; Visualization, M.S.; Supervision, E.B.-S. All authors have read and agreed to the published version of the manuscript.

Funding: This research did not receive any specific grant from any funding agency in the public, commercial, or non-profit sector.

Acknowledgments: The authors thank the reviewers for thoughtful and thorough review.

Conflicts of Interest: The authors declare no conflict of interest.

$\begin{array}{ll}\text { Abbreviations } \\ \text { AI } & \text { adrenal incidentaloma; } \\ \text { AIx } & \text { augmentation index; } \\ \text { ACC } & \text { adrenal cortical carcinoma; } \\ \text { ACS } & \text { autonomous cortisol secretion; } \\ \text { AI } & \text { adrenal incidentaloma; } \\ \text { BSA } & \text { body surface area; } \\ \text { CIMT } & \text { carotid intima-media thickness; } \\ \text { CS } & \text { Cushing's syndrome; } \\ \text { CVD } & \text { cardiovascular disease; } \\ \text { CVR } & \text { cardiovascular risk; }\end{array}$




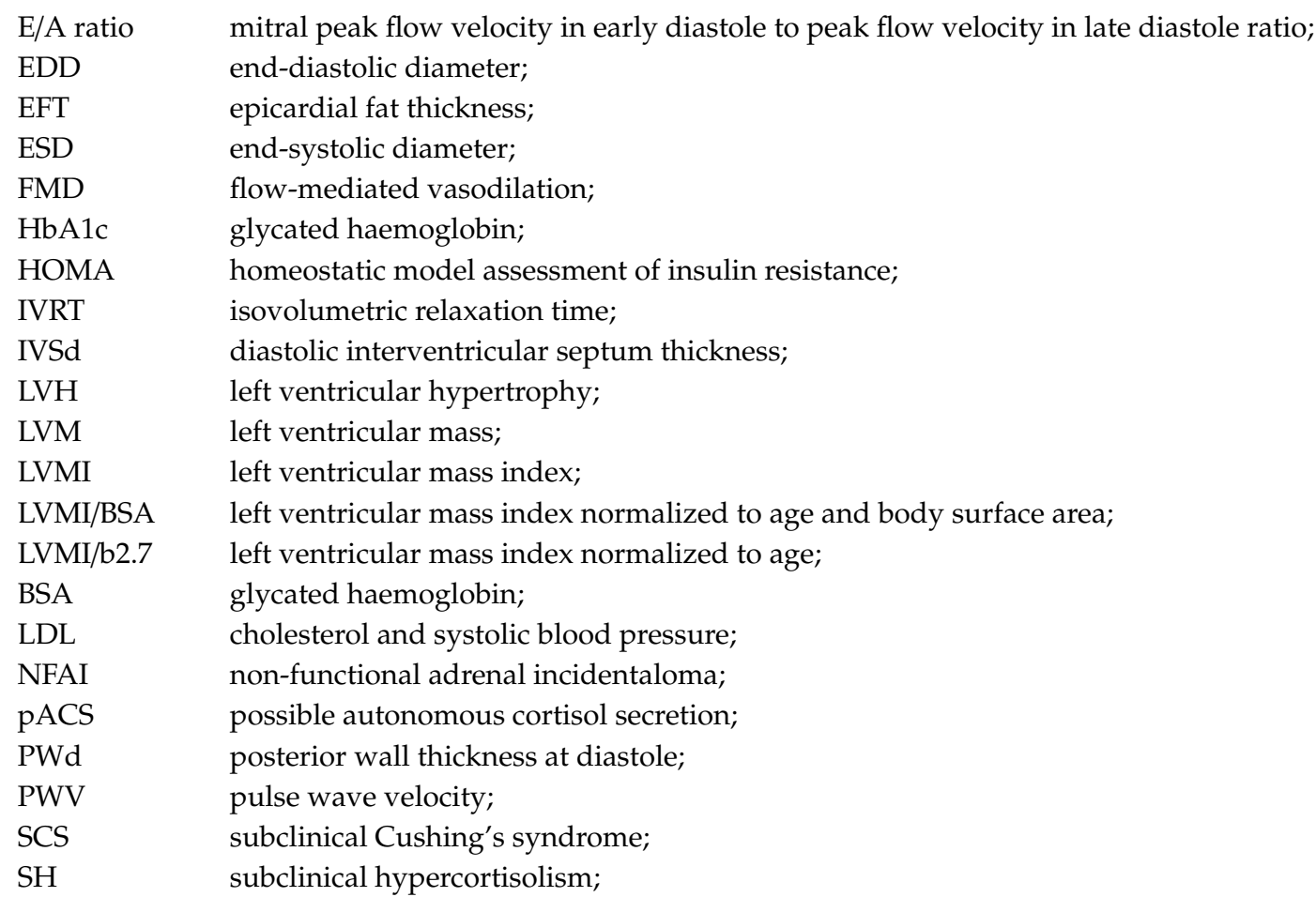

\section{References}

1. NIH state-of-the-science statement on management of the clinically inapparent adrenal mass ("incidentaloma"). NIH Consens State Sci. Statements 2002, 19, 1-25.

2. Terzolo, M.; Pia, A.; Alì, A.; Osella, G.; Reimondo, G.; Bovio, S.; Daffara, F.; Procopio, M.; Paccotti, P.; Borretta, G.; et al. Adrenal incidentaloma: A new cause of the metabolic syndrome? J. Clin. Endocrinol. Metab. 2002, 87, 998-1003. [CrossRef]

3. Song, J.H.; Chaudhry, F.S.; Mayo-Smith, W.W. The incidental adrenal mass on CT: Prevalence of adrenal disease in 1,049 consecutive adrenal masses in patients with no known malignancy. AJR Am. J. Roentgenol. 2008, 190, 1163-1168. [CrossRef]

4. Bovio, S.; Cataldi, A.; Reimondo, G.; Sperone, P.; Novello, S.; Berruti, A.; Borasio, P.; Fava, C.; Dogliotti, L.; Scagliotti, G.V.; et al. Prevalence of adrenal incidentaloma in a contemporary computerized tomography series. J. Endocrinol. Invest. 2006, 29, 298-302. [CrossRef] [PubMed]

5. Terzolo, M.; Stigliano, A.; Chiodini, I.; Loli, P.; Furlani, L.; Arnaldi, G.; Reimondo, G.; Pia, A.; Toscano, V.; Zini, M.; et al. AME position statement on adrenal incidentaloma. Eur. J. Endocrinol. 2011, 164, 851-870. [CrossRef]

6. Fassnacht, M.; Arlt, W.; Bancos, I.; Dralle, H.; Newell-Price, J.; Sahdev, A.; Tabarin, A.; Terzolo, M.; Tsagarakis, S.; Dekkers, O.M. Management of adrenal incidentalomas: European society of endocrinology clinical practice guideline in collaboration with the European network for the study of adrenal tumors. Eur. J. Endocrinol. 2016, 175, G1-G34. [CrossRef] [PubMed]

7. Bednarczuk, T.; Bolanowski, M.; Sworczak, K.; Górnicka, B.; Cieszanowski, A.; Otto, M.; Ambroziak, U.; Pachucki, J.; Kubicka, E.; Babińska, A.; et al. Przypadkowo wykryty guz nadnercza (incydentaloma) $\mathrm{u}$ dorosłych-Zasady postępowania rekomendowane przez Polskie Towarzystwo Endokrynologiczne. Endokrynol. Pol. 2016, 67, 234-258. [CrossRef]

8. Funder, J.W.; Carey, R.M.; Mantero, F.; Murad, M.H.; Reincke, M.; Shibata, H.; Stowasser, M.; Young, W.F. The Management of Primary Aldosteronism: Case Detection, Diagnosis, and Treatment: An Endocrine Society Clinical Practice Guideline. J. Clin. Endocrinol. Metab. 2016, 101, 1889-1916. [CrossRef]

9. Lenders, J.W.; Duh, Q.Y.; Eisenhofer, G.; Gimenez-Roqueplo, A.P.; Grebe, S.; Murad, M.; Naruse, M.; Pacak, K.; Young, W. Pheochromocytoma and Paraganglioma: An Endocrine Society Clinical Practice Guideline. J. Clin. Endocrinol. Metab. 2014, 99, 1915-1942. [CrossRef] 
10. Mansmann, G.; Lau, J.; Balk, E.; Rothberg, M.; Miyachi, Y.; Bornstein, S.R. The Clinically Inapparent Adrenal Mass: Update in Diagnosis and Management. Endocr. Rev. 2004, 25, 309-340. [CrossRef]

11. Grumbach, M.M.; Biller, B.M.K.; Braunstein, G.D.; Campbell, K.K.; Aidan Carney, J.; Godley, P.A.; Harris, E.L.; Lee, J.K.T.; Oertel, Y.C.; Posner, M.C.; et al. Management of the clinically inapparent adrenal mass ("incidentaloma"). Ann. Intern. Med. 2003, 138, 424-429. [CrossRef] [PubMed]

12. Fassnacht, M.; Libé, R.; Kroiss, M.; Allolio, B. Adrenocortical carcinoma: A clinician's update. Nat. Rev. Endocrinol. 2011, 7, 323-335. [CrossRef]

13. Dobbie, J.W. Adrenocortical nodular hyperplasia: The ageing adrenal. J. Pathol. 1969, 99, 1-18. [CrossRef] [PubMed]

14. Pillion, D.J.; Arnold, P.; Yang, M.; Stockard, C.R.; Grizzle, W.E. Receptors for insulin and insulin-like growth factor-I in the human adrenal gland. Biochem. Biophys. Res. Commun. 1989, 165, 204-211.

15. Reincke, M.; Fassnacht, M.; Väth, S.; Mora, P.; Allolio, B. Adrenal incidentalomas: A manifestation of the metabolic syndrome? Endocr. Res. 1996, 22, 757-761. [CrossRef] [PubMed]

16. Vassiliadi, D.A.; Tzanela, M.; Tsatlidis, V.; Margelou, E.; Tampourlou, M.; Mazarakis, N.; Piaditis, G.; Tsagarakis, S. Abnormal responsiveness to dexamethasone-suppressed CRH test in patients with bilateral adrenal incidentalomas. J. Clin. Endocrinol. Metab. 2015, 100, 3478-3485. [CrossRef]

17. Bertagna, X. Genetics of adrenal diseases in 2014: Genetics improves understanding of adrenocortical tumours. Nat. Rev. Endocrinol. 2014, 11,77-78. [CrossRef]

18. Lerario, A.M.; Moraitis, A.; Hammer, G.D. Genetics and epigenetics of adrenocortical tumors. Mol. Cell. Endocrinol. 2014, 386, 67-84. [CrossRef]

19. Bonnet-Serrano, F.; Bertherat, J. Genetics of tumors of the adrenal cortex. Endocr. Relat. Cancer 2018, 25, R131-R152. [CrossRef]

20. Kiszczak-Bochyńska, E.; Oszywa, A.; Kurowska, M.; Malicka, J.; Dudzińska, M.; Tarach, J. Features of metabolic syndrome in patients with adrenal incidentalomas. Family Med. Primary Care Rev. 2014, 16, 242-244.

21. Isidori, A.M.; Graziadio, C.; Paragliola, R.M.; Cozzolino, A.; Ambrogio, A.G.; Colao, A.; Corsello, S.M.; Pivonello, R.; ABC Study Group. The hypertension of Cushing's syndrome: Controversies in the pathophysiology and focus on cardiovascular complications. J. Hypertens. 2015, 33, 44-60. [CrossRef] [PubMed]

22. Yiu, K.H.; Marsan, N.A.; Delgado, V.; Biermasz, N.R.; Holman, E.R.; Smit, J.W.; Feelders, R.A.; Bax, J.J.; Pereira, A.M. Increased myocardial fibrosis and left ventricular dysfunction in Cushing's syndrome. Eur. J. Endocrinol. 2012, 166, 27-34. [CrossRef] [PubMed]

23. Rossi, R.; Tauchmanova, L.; Luciano, A.; Di Martino, M.; Battista, C.; Del Viscovo, L.; Nuzzo, V.; Lombardi, G. Subclinical Cushing's syndrome in patients with adrenal incidentaloma: Clinical and biochemical features. J. Clin. Endocrinol. Metab. 2000, 85, 1440-1448.

24. De Leo, M.; Cozzolino, A.; Colao, A.; Pivonello, R. Subclinical Cushing's syndrome. Best Pract. Res. Clin. Endocrinol. Metab. 2012, 26, 497-505. [CrossRef]

25. Nieman, L.K. Cushing's syndrome: Update on signs, symptoms and biochemical screening. Eur. J. Endocrinol. 2015, 173, M33-M38. [CrossRef] [PubMed]

26. Barzon, L.; Sonino, N.; Fallo, F.; Palu, G.; Boscaro, M. Prevalence and natural history of adrenal incidentalomas. Eur. J. Endocrinol. 2003, 149, 273-285. [CrossRef] [PubMed]

27. Libe, R.; Dall'Asta, C.; Barbetta, L.; Baccarelli, A.; Beck-Peccoz, P.; Ambrosi, B. Long-term follow-up study of patients with adrenal incidentalomas. Eur. J. Endocrinol. 2002, 147, 489-494. [CrossRef]

28. Bernini, G.P.; Moretti, A.; Oriandini, C.; Bardini, M.; Taurino, C.; Salvetti, A. Long-term morphological and hormonal follow-up in a single unit on 115 patients with adrenal incidentalomas. Br. J. Cancer 2005, 92, 1104-1109. [CrossRef]

29. Terzolo, M.; Bovio, S.; Pia, A.; Conton, P.A.; Reimondo, G.; Dall'Asta, C.; Bemporad, D.; Angeli, A.; Opocher, G.; Mannelli, M.; et al. Midnight serum cortisol as a marker of increased cardiovascular risk in patients with a clinically inapparent adrenal adenoma. Eur. J. Endocrinol. 2005, 153, 307-315. [CrossRef]

30. Nieman, L.; Biller, B.; Findling, J.W.; Newell-Price, J.; Savage, M.O.; Stewart, P.M.; Montori, V.M. The diagnosis of Cushing's syndrome: An Endocrine Society Clinical Practice Guideline. J. Clin. Endocrinol. Metab. 2008, 93, 1526-1540. [CrossRef] 
31. Guignat, L.; Bertherat, J. The diagnosis of Cushing's syndrome: An Endocrine Society Clinical Practice Guideline: Commentary from a European perspective. Eur. J. Endocrinol. 2010, 163, 9-13. [CrossRef] [PubMed]

32. Tsagarakis, S.; Vassiliadi, D.; Thalassinos, N. Endogenous subclinical hypercortisolism: Diagnostic uncertainties and clinical implications. J. Endocrinol. Investig. 2006, 29, 471-482. [CrossRef] [PubMed]

33. Valassi, E.; Swearingen, B.; Lee, H.; Nachtigall, L.B.; Donoho, D.A.; Klibanski, A.; Biller, B.M. Concomitant medication use can confound interpretation of the combined dexamethasone-corticotropin releasing hormone test in Cushing's syndrome. J. Clin. Endocrinol. Metab. 2009, 94, 4851-4859. [CrossRef] [PubMed]

34. Bansal, V.; El Asmar, N.; Selman, W.; Arafah, B.M. Pitfalls in the diagnosis and management of Cushing's syndrome. Neurosurg. Focus. 2015, 38, E4. [CrossRef]

35. Chiodini, I. Clinical review: Diagnosis and treatment of subclinical hypercortisolism. J. Clin. Endocrinol. Metab. 2011, 96, 1223-1236. [CrossRef]

36. Debono, M.; Newell-Price, J. Subclinical hypercortisolism in adrenal incidentaloma. Curr. Opin. Endocrinol. Diabetes Obes. 2015, 22, 185-192. [CrossRef]

37. Di Dalmazi, G.; Vicennati, V.; Rinaldi, E.; Morselli-Labate, A.M.; Giampalma, E.; Mosconi, C.; Pagotto, U.; Pasquali, R. Progressively increased patterns of subclinical cortisol hypersecretion in adrenal incidentalomas differently predict major metabolic and cardiovascular outcomes: A large cross-sectional study. Eur. J. Endocrinol. 2012, 166, 669-677. [CrossRef]

38. Anagnostis, P.; Goulis, D.G. Cushing's Syndrome and Cardiovascular Risk. Curr. Vasc. Pharmacol. 2020, 18, 12-24. [CrossRef]

39. Tsuiki, M.; Tanabe, A.; Takagi, S.; Naruse, M.; Takano, K. Cardiovascular risks and their long-term clinical outcome in patients with subclinical Cushing's syndrome. Endocr. J. 2008, 55, 737-745. [CrossRef]

40. Di Dalmazi, G.; Vicennati, V.; Garelli, S.; Casadio, E.; Rinaldi, E.; Giampalma, E.; Mosconi, C.; Golfieri, R.; Paccapelo, A.; Pagotto, U.; et al. Cardiovascular events and mortality in patients with adrenal incidentalomas that are either non-secreting or associated with intermediate phenotype or subclinical Cushing's syndrome: A 15-year retrospective study. Lancet Diabetes Endocrinol. 2014, 2, 396-405. [CrossRef]

41. Morelli, V.; Reimondo, G.; Giordano, R.; Della Casa, S.; Policola, C.; Palmieri, S.; Salcuni, A.S.; Dolci, A.; Mendola, M.; Arosio, M.; et al. Long-term follow-up in adrenal incidentalomas: An Italian multicenter study. J. Clin. Endocrinol. Metab. 2014, 99, 827-834. [CrossRef] [PubMed]

42. Di Dalmazi, G.; Pasquali, R. Adrenal adenomas, subclinical hypercortisolism, and cardiovascular outcomes. Curr. Opin. Endocrinol. Diabetes Obes. 2015, 22, 163-168. [CrossRef] [PubMed]

43. Debono, M.; Bradburn, M.; Bull, M.; Harrison, B.; Ross, R.J.; Newell-Price, J. Cortisol as a marker for increased mortality in patients with incidental adrenocortical adenomas. J. Clin. Endocrinol. Metab. 2014, 99, 4462-4470. [CrossRef]

44. Morelli, V.; Palmieri, S.; Lania, A.; Tresoldi, A.; Corbetta, S.; Cairoli, E.; Eller-Vainicher, C.; Arosio, M.; Copetti, M.; Grossi, E.; et al. Cardiovascular events in patients with mild autonomous cortisol secretion: Analysis with artificial neural networks. Eur. J. Endocrinol. 2017, 177, 73-83. [CrossRef] [PubMed]

45. Patrova, J.; Kjellman, M.; Wahrenberg, H.; Falhammar, H. Increased mortality in patients with adrenal incidentalomas and autonomous cortisol secretion: A 13-year retrospective study from one center. Endocrine 2017, 58, 267-275. [CrossRef] [PubMed]

46. Garrapa, G.; Pantanetti, P.; Arnaldi, G.; Mantero, F.; Faloia, E. Body composition and metabolic features in women with adrenal incidentaloma or Cushing's syndrome. J. Clin. Endocrinol. Metab. 2001, 86, 5301-5306.

47. Peppa, M.; Boutati, E.; Koliaki, C.; Papaefstathiou, N.; Garoflos, E.; Economopoulos, T.; Hadjidakis, D.; Raptis, S.A. Insulin resistance and metabolic syndrome in patients with nonfunctioning adrenal incidentalomas: A cause-effect relationship? Metabolism 2010, 59, 1435-1441. [CrossRef]

48. Peppa, M.; Koliaki, C.; Raptis, S. Adrenal incidentalomas and cardiometabolic morbidity: An emerging association with serious clinical implications. J. Intern. Med. 2010, 268, 555-566. [CrossRef]

49. Lopez, D.; Luque-Fernandez, M.A.; Steele, A.; Adler, G.K.; Turchin, A.; Vaidya, A. “Nonfunctional” adrenal tumors and the risk for incident diabetes and cardiovascular outcomes: A cohort study. Ann. Intern. Med. 2016, 165, 533-542. [CrossRef]

50. Iwakiri, T.; Yano, Y.; Sato, Y.; Hatakeyama, K.; Marutsuka, K.; Fujimoto, S.; Kitamura, K.; Kario, K.; Asada, Y. Usefulness of carotid intima-media thickness measurement as an indicator of generalized atherosclerosis: Findings from autopsy analysis. Atherosclerosis 2012, 225, 359-362. [CrossRef] 
51. Lorenz, M.W.; Markus, H.S.; Bots, M.L.; Rosvall, M.; Sitzer, M. Prediction of clinical cardiovascular events with carotid intima-media thickness: A systematic review and meta-analysis. Circulation 2007, 115, 459-467. [CrossRef] [PubMed]

52. O'Leary, D.H.; Polak, J.F.; Kronmal, R.A.; Manolio, T.A.; Burke, G.L.; Wolfson, S.K., Jr. Carotid-artery intima and media thickness as a risk factor for myocardial infarction and stroke in older adults. Cardiovascular Health Study Collaborative Research Group. N. Engl. J. Med. 1999, 340, 14-22. [CrossRef] [PubMed]

53. van Popele, N.M.; Grobbee, D.E.; Bots, M.L.; Asmar, R.; Topouchian, J.; Reneman, R.S.; Hoeks, A.P.; van der Kuip, D.A.; Hofman, A.; Witteman, J.C. Association between arterial stiffness and atherosclerosis: The Rotterdam Study. Stroke 2001, 32, 454-460. [CrossRef] [PubMed]

54. Tauchmanovà, L.; Rossi, R.; Biondi, B.; Pulcrano, M.; Nuzzo, V.; Palmieri, E.A.; Fazio, S.; Lombardi, G. Patients with subclinical Cushing's syndrome due to adrenal adenoma have increased cardiovascular risk. J. Clin. Endocrinol. Metab. 2002, 87, 4872-4878. [CrossRef] [PubMed]

55. Androulakis, I.I.; Kaltsas, G.A.; Kollias, G.E.; Markou, A.C.; Gouli, A.K.; Thomas, D.A.; Alexandraki, K.I.; Papamichael, C.M.; Hadjidakis, D.J.; Piaditis, G.P. Patients with apparently nonfunctioning adrenal incidentalomas may be at increased cardiovascular risk due to excessive cortisol secretion. J. Clin. Endocrinol. Metab. 2014, 99, 2754-2762. [CrossRef] [PubMed]

56. Imga, N.N.; Ucar, E.; Muslum, T.; Aycıcek Dogan, B.; Sahin, D.; Berker, D.; Guler, S. The Relationship between Increased Epicardial Fat Thickness and Left Ventricular Hypertrophy and Carotid Intima-Media Thickness in Patients With Nonfunctional Adrenal Incidentaloma. Int. J. Endocrinol. Metab. 2016, 14, e37635. [CrossRef]

57. Tuna, M.; Imga, N.; Aycicek, B.; Yılmaz, F.M.; Topçuoğlu, C.; Akbaba, G.; Berker, D.; Güler, S. Non-functioning adrenal incidentalomas are associated with higher hypertension prevalence and higher risk of atherosclerosis. J. Endocrinol. Investig. 2014, 37, 765-768. [CrossRef]

58. Evran, M.; Akkuş, G.; Berk Bozdoğan, İ.; Gök, M.; Deniz, A.; Sert, M.; Tetiker, T. Carotid Intima-Media Thickness as the Cardiometabolic Risk Indicator in Patients with Nonfunctional Adrenal Mass and Metabolic Syndrome Screening. Med. Sci. Monit. 2016, 22, 991-997. [CrossRef]

59. Cansu, G.B.; Sarı, R.; Yılmaz, N.; Özdem, S.; Çubuk, M. Markers of Subclinical Cardiovascular Disease in Nonfunctional Adrenal Incidentaloma Patients without Traditional Cardiovascular Risk Factors. Exp. Clin. Endocrinol. Diabetes 2017, 125, 57-63. [CrossRef]

60. Emral, R.; Aydoğan, B.İ.; Köse, A.D.; Demir, Ö.; Çorapçığlu, D. Could a nonfunctional adrenal incidentaloma be a risk factor for increased carotid intima-media thickness and metabolic syndrome. Endocrinol. Diabetes Nutr. 2019, 66, 402-409. [CrossRef]

61. Mattace-Raso, F.U.; van der Cammen, T.J.; Hofman, A.; van Popele, N.M.; Bos, M.L.; Schalekamp, M.A.; Asmar, R.; Reneman, R.S.; Hoeks, A.P.; Breteler, M.M.; et al. Arterial stiffness and risk of coronary heart disease and stroke: The Rotterdam Study. Circulation 2006, 113, 657-663. [CrossRef] [PubMed]

62. Cavalcante, J.L.; Lima, J.A.; Redheuil, A.; Al-Mallah, M.H. Aortic Stiffness-Current Understanding and Future Directions. J. Am. Coll. Cardiol. 2011, 57, 1511-1522. [CrossRef] [PubMed]

63. Akkan, T.; Altay, M.; Ünsal, Y.; Dağdeviren, M.; Beyan, E. Nonfunctioning adrenal incidentaloma affecting central blood pressure and arterial stiffness parameters. Endocrine 2017, 58, 513-520. [CrossRef]

64. Sbardella, E.; Minnetti, M.; D’Aluisio, D.; Rizza, L.; Di Giorgio, M.R.; Pofi, R.; Giannetta, E.; Vestri, A.; Venneri, M.; Morelli, S.; et al. Cardiovascular features of possible autonomous cortisol secretion in patients with adrenal incidentalomas. Eur. J. Endocrinol. 2018, 178, 501-511. [CrossRef]

65. Corretti, M.C.; Anderson, T.J.; Benjamin, E.J.; Celermajer, D.S.; Charbonneau, F.; Creager, M.A.; Deanfield, J.E.; Drexler, H.; Gerhard-Herman, M.D.; Herrington, D.; et al. Guidelines for the ultrasound assessment of endothelial-dependent flow-mediated vasodilation of the brachial artery: A report of the International Brachial Artery Reactivity Task Force. J. Am. Coll. Cardiol. 2002, 39, 257-265. [CrossRef]

66. Fathi, R.; Haluska, B.; Isbel, N.; Short, L.; Marwick, T.H. The relative importance of vascular structure and function in predicting cardiovascular events. J. Am. Coll. Cardiol. 2004, 43, 616-623. [CrossRef]

67. Grajek, S. Przebudowa serca na poziomie narządowym. Defin. Klasyf. Kardiol. Pol. 2000, 53, $28-32$.

68. Lorell, B.; Carabello, B. Left ventricular hypertrophy: Pathogenesis, detection, and prognosis. Circulation 2000, 102, 470-479. [CrossRef] [PubMed]

69. Katholi, R.; Couri, D. Left Ventricular Hypertrophy: Major Risk Factor in Patients with Hypertension: Update and Practical Clinical Applications. Int. J. Hypertens. 2011, 2011, 495349. [CrossRef] [PubMed] 
70. Lip, G.; Felmeden, D.C.; Li-Saw-Hee, F.L.; Beevers, D.G. Hypertensive heart disease. A complex syndrome or a hypertensive "cardiomyopathy”? Eur. Heart J. 2000, 21, 1653-1665. [CrossRef]

71. Kannel, W.; Dannenberg, A.; Levy, D. Population implications of ECG left ventricular hypertrophy. Am. J. Cardiol. 1991, 19, 1287-1294.

72. Iacobellis, G.; Ribaudo, M.; Assael, F.; Vecci, E.; Tiberti, C.; Zappaterreno, A.; Di Mario, U.; Leonetti, F. Echocardiographic Epicardial Adipose Tissue Is Related to Anthropometric and Clinical Parameters of Metabolic Syndrome: A New Indicator of Cardiovascular Risk. J. Clin. Endocrinol. Metab. 2003, 88, 5163-5168. [CrossRef] [PubMed]

73. Iacobellis, G. Epicardial adipose tissue in endocrine and metabolic diseases. Endocrine 2014, 46, 8-15. [CrossRef] [PubMed]

74. Rosito, G.A.; Massaro, J.M.; Hoffmann, U.; Ruberg, F.; Mahabadi, A.; Vasan, R.; O’Donnell, C.; Fox, C. Pericardial fat, visceral abdominal fat, cardiovascular disease risk factors, and vascular calcification in a community-based sample: The Framingham Heart Study. Circulation 2008, 11, 605-613. [CrossRef]

75. Cheng, K.; Chu, C.; Lee, K.; Lin, T.; Hsieh, C.; Chiu, C.; Voon, W.; Sheu, S.; Lai, W. Adipocytokines and proinflammatory mediators from abdominal and epicardial adipose tissue in patients with coronary artery disease. Int. J. Obes. 2008, 32, 268-274. [CrossRef]

76. Alexopoulos, N.; McLean, D.; Janik, M.; Arepalli, C.; Stillman, A.; Raggi, P. Epicardial adipose tissue and coronary artery plaque characteristics. Atherosclerosis 2010, 210, 150-154. [CrossRef]

77. Ding, J.; Hsu, F.; Harris, T.; Liu, Y.; Kritchevsky, S.; Szklo, M.; Ouyang, P.; Espeland, M.; Lohman, K.; Criqui, M.; et al. The association of pericardial fat with incident coronary heart disease: The Multi-Ethnic Study of Atherosclerosis (MESA). Am. J. Clin. Nutr. 2009, 90, 499-504. [CrossRef]

78. Iacobellis, G.; Ribaudo, M.; Zappaterreno, A.; Iannucci, C.V.; Leonetti, F. Relation between epicardial adipose tissue and left ventricular mass. Am. J. Cardiol. 2004, 94, 1084-1087. [CrossRef]

79. Ermetici, F.; Dall'Asta, C.; Malavazos, A.E.; Coman, C.; Morricone, L.; Montericcio, V.; Ambrosi, B. Echocardiographic alterations in patients with non-functioning adrenal incidentaloma. J. Endocrinol. Investig. 2008, 31, 573. [CrossRef]

80. Iacobellis, G.; Petramala, L.; Barbaro, G.; Kargi, A.Y.; Serra, V.; Zinnamosca, L.; Colangelo, L.; Marinelli, C.; Ciardi, A.; De Toma, G.; et al. Epicardial fat thickness and left ventricular mass in subjects with adrenal incidentaloma. Endocrine 2013, 44, 532-536. [CrossRef]

81. Imga, N.; Elalmıs, O.; Tuna, M.; Dogan, B.; Gursoy, T.; Yalcına, Y.; Berker, D.; Gulera, S. Comparison of echocardiographic findings in patients with nonfunctioning adrenal incidentalomas. Kaohsiung J. Med. Sci. 2017, 33, 295-301. [CrossRef]

82. Sokmen, G.; Şahin, M.; Tuzun, D.; Sokmen, A.; Bolat, H.; Oguz, A.; Doganer, A.; Nacar, H.; Gul, K. Assessment of Subclinical Cardiac Alterations and Atrial Electromechanical Delay by Tissue Doppler Echocardiography in Patients with Nonfunctioning Adrenal Incidentaloma. Arq. Bras. Cardiol. 2018, 111, 656-663. [CrossRef]

83. Whitworth, J.A.; Williamson, P.M.; Mangos, G.; Kelly, J.J. Cardiovascular consequences of cortisol excess. Vasc. Health Risk Manag. 2005, 1, 291-299. [CrossRef] [PubMed]

84. Chiodini, I.; Morelli, V.; Salcuni, A.S.; Eller-Vainicher, C.; Torlontano, M.; Coletti, F.; Iorio, L.; Cuttitta, A.; Ambrosio, A.; Vicentini, L.; et al. Beneficial metabolic effects of prompt surgical treatment in patients with an adrenal incidentaloma causing biochemical hypercortisolism. J. Clin. Endocrinol. Metab. 2010, 95, 2736-2745. [CrossRef] [PubMed]

85. Iacobone, M.; Citton, M.; Viel, G.; Bonadio, I.; Mondi, I.; Tropea, S.; Nitti, D.; Favia, G. Adrenalectomy may improve cardiovascular and metabolic impairment and ameliorate quality of life in patients with adrenal incidentalomas and subclinical Cushing's syndrome. Surgery 2012, 152, 991-997. [CrossRef] [PubMed]

86. Mitchell, I.; Juneja, K.; Chang, A.; Holt, S.; Snyder, W.; Nwariaku, F. "Subclinical Cushing's syndrome" is not subclinical: Improvement after adrenalectomy in 9 patients. Surgery 2007, 142, 900-905. [CrossRef]

87. Bancos, I.; Alahdab, F.; Crowley, R.; Chortis, V.; Delivanis, D.A.; Erickson, D.; Natt, N.; Terzolo, M.; Arlt, W.; Young, W.F.; et al. Improvement of cardiovascular risk factors after adrenalectomy in patients with adrenal tumors and subclinical Cushing's syndrome: A systematic review and meta-Analysis. Eur. J. Endocrinol. 2016, 175, R283-R295. [CrossRef] 
88. Raffaelli, M.; De Crea, C.; D'Amato, G.; Gallucci, P.; Lombardi, C.P.; Bellantone, R. Outcome of adrenalectomy for subclinical hypercortisolism and Cushing syndrome. Surgery 2017, 161, 264-271. [CrossRef]

(C) 2020 by the authors. Licensee MDPI, Basel, Switzerland. This article is an open access article distributed under the terms and conditions of the Creative Commons Attribution (CC BY) license (http://creativecommons.org/licenses/by/4.0/). 